\title{
Towards a Criminal Chamber in the African Court of Justice and Human Rights
}

\author{
Chacha Bhoke Murungu*
}

\begin{abstract}
The African Union (AU) intends to establish a Criminal Chamber within the African Court of Justice and Human Rights (the Criminal Chamber) to prosecute persons responsible for international crimes in Africa. This article argues that calls by the AU to establish the Criminal Chamber arise from a chain of events beginning with the indictment and prosecution of some African individuals, including state officials, by the Prosecutor of the International Criminal Court (ICC) and the authorities in domestic courts of European states. It examines the basis for, and likely problems associated with, the establishment of a Criminal Chamber. It concludes that by establishing such a chamber, African states parties to the Rome Statute will act in breach of their obligations under that treaty. It recommends that African states and the AU must respect their international law obligations arising from the Rome Statute.
\end{abstract}

\section{Introduction}

The African Union (AU) is determined to establish a Criminal Chamber within the African Court of Justice and Human Rights (the Criminal Chamber). Recognizing that the African Court of Justice and Human Rights (the African Court) does not have jurisdiction over individuals responsible for international crimes, the AU has embarked on a study to assess the feasibility of establishing the Criminal Chamber.

In its summit held at Addis Ababa in February 2009, the AU Assembly took a decision (Assembly/AU/Dec. 213(XII)) in which it requested the African Union Commission (AU Commission) in consultation with the African Commission on Human and Peoples' Rights (the African Commission) to assess the implications of recognising the jurisdiction of the African Court to try international crimes such as genocide, crimes against humanity and war crimes. In its Decision Assembly/AU/Dec. 292(XV) of July 2010, the AU Assembly further requested the AU Commission to finalise the study on the implications of extending jurisdiction of the African Court to cover international crimes, and to submit, through the Executive Council, a report thereon to the regular session of the AU Assembly scheduled for January 2011. 
To implement the AU decisions above, the AU Commission engaged consultants to examine the implications of extending the jurisdiction of the African Court to include international crimes, and to draft a Protocol for the establishment of the Criminal Chamber within the African Court. ${ }^{1}$ The consultants, led by Mr Donald Deya (of the Pan African Lawyers Union) completed their study and submitted it to the AU Commission. Annexed to the study was the Draft Protocol on the Amendments to the Protocol on the Statute of the African Court of Justice and Human Rights (Legal/ACJHR-PAP/4(II) Rev.2). In August 2010 and on 8 -12 November 2010, the AU Commission organised two workshops held at Midrand, South Africa, to validate the study findings.

At its summit of 30 June - 1 July 2011 held at Malabo, Equatorial Guinea, the AU Assembly adopted Decision Assembly/AU/Dec. 366 (XVII) in which it requested the AU Commission to actively pursue the implementation of the AU Assembly decisions on the African Court being empowered to try serious international crimes committed on African soil and report to the AU Assembly. The AU Commission will submit findings on the establishment of the Criminal Chamber to the AU Assembly for a decision in January 2012. It is expected that in January 2012 the AU Assembly will adopt a Protocol on the Amendments to the Protocol on the Statute of the African Court of Justice and Human Rights. After attaining necessary ratifications, this Protocol will empower the African Court to exercise criminal jurisdiction over most serious international crimes committed in Africa.

\section{Prelude to the Criminal Chamber in the African Court}

Arguably, there is one main factor that has led to the calls for the establishment of a Criminal Chamber within the African Court. This is the indictment and prosecution of African state officials either by the domestic courts of some European states, especially France, the United Kingdom, Spain and Belgium, or by the International Criminal Court.

\footnotetext{
* LL.B (Hons) Dar es Salaam; LL.M; LL.D, Centre for Human Rights, Faculty of Law, University of Pretoria; Advocate of the High Court of Tanzania. I am indebted to Prof Curtis Francis Doebbler for his comments on the initial draft of this article. I am also grateful to the anonymous reviewers whose comments shaped the structure of this article. I bear responsibility for the contents herein. [cbmurungu@gmail.com]

${ }^{1}$ In the July 2010 AU Summit at Kampala, Uganda, the AU Assembly did not address the issue of the Criminal Chamber. It is expected that in January 2012 the AU Assembly will decide on the adoption of the Protocol for the establishment of the Criminal Chamber within the African Court.
} 
This paper will critically analyse this proposition, considered under two sub-factors: the long term causes, on the one hand, and the immediate ones, on the other. In a nutshell, the long term causes comprise both the indictment of African state officials before the domestic courts of some European states, and cases that have been brought before the International Court of Justice (ICJ) - all involving African state officials.

The immediate cause arguably relates to criminal proceedings against the sitting Sudanese president, Omar Hassan Al Bashir. Following Omar Bashir's indictment by the ICC Prosecutor, the AU reacted with a deliberate move and decided, first, not to cooperate with the ICC; second, to establish a Criminal Chamber within the African Court. Below is the discussion on these two factors, followed by an analysis of the legal basis for the proposed Criminal Chamber, and the problems raised by its establishment.

\section{A. Long Term Factors for the Establishment of the Criminal Chamber}

\section{Indictments or Prosecution of African State Officials in Europe}

In order to better grasp the reasons that led to the proposed establishment of the Criminal Chamber it is useful to recall the numerous proceedings that were instituted in Europe against African state officials. It is perhaps ironical to recall when the Libyan leader, Muamar Qaddafi was indicted in France for torture and conspiracy to commit torture and terrorist acts, the Court of Cassation of France rendered its judgement in favour of Qaddafi. ${ }^{2}$ The former President of Mauritania, Maaouya Ould Sid'Ahmed Taya was also indicted in France in $2005 .{ }^{3}$ Rwandan state officials have also been subjects to indictments in respect of international crimes committed in Rwanda in 1994. In 2007, a French judge, Jean-Louis Bruguière, indicted Rwandan state and military officials for their alleged roles in the 1994 genocide in Rwanda. However, an arrest warrant could not be issued against President Paul Kagame due to his immunity from prosecution. Instead, Rose Kabuye, a Rwandan state official who visited Germany in 2008, was arrested and extradited to France. Kabuye had been indicted in France for her role in the Rwandan genocide. The German authorities failed to prosecute Kabuye because of the provisions of sections 18, 19 and 20 of 'the German Judiciary Act', which grant immunity to

\footnotetext{
${ }^{2}$ SOS Attentats et Beatrice Castelnau d'Esnault c. Gadafy, 125 ILR 490, 508, 13 March 2001.

${ }^{3}$ International Federation of Human Rights Defenders (FIDH) and Others v Ould Dah, 8 July 2002, Court of Appeal of Nimes, 1 July 2005 (Nimes Assize Court, France).
} 
diplomatic missions and state officials on official invitation in Germany. ${ }^{4}$ Criminal proceedings in France were terminated by a court in Paris, and Kabuye was released after a French judicial investigation found her not guilty of the crimes as charged. The prosecution of this Rwandan state official in France resulted in a diplomatic row between Rwanda and France, which saw Rwanda denounce its diplomatic ties with France. However, diplomatic relations between the two states have since been restored.

In early 2009, a court in Paris issued indictments against five serving African presidents alleging corruption, namely: Denis Sassou Nguesso of Congo; Teodoro Obiang Nguema of Equatorial Guinea; Omar Bongo of Gabon; Blaise Compaoré of Burkina Faso and Eduardo Dos Santos of Angola. ${ }^{5}$ Omar Bongo of Gabon died later in 2009.

Robert Mugabe, the President of Zimbabwe was fortunately saved by a Magistrate's Court in England in January 2004 following a private application for his arrest and extradition in England. ${ }^{6}$ The Bow Street Magistrate's Court relied on the rules of customary international law on immunity of serving heads of state to reject the application against Robert Mugabe. ${ }^{7}$ Regarding Robert Mugabe, it should be recalled that several civil suits were instituted in the courts of the United States of America on allegations of torture, but the Court of Appeals for the Second Circuit held that President Mugabe enjoyed an absolute inviolability and immunity from that country's courts. ${ }^{8}$

On 23 December 1998, the Spanish Audiencia Nacional decided in favour of the President of Equatorial Guinea, Mr. Obiang Nguema. ${ }^{9}$ In February 2008, the Audiencia

\footnotetext{
${ }^{4}$ Amnesty International, Germany: End Impunity through Universal Jurisdiction, (Amnesty International Publications, No Safe Haven Series, No.3, 2008) 70.

${ }^{5}$ 'Five African Leaders sued for Corruption', Radio France International, available at http://www.rfi.fr/actuen/articles/103/article_960.asp (visited 19 October 2010).

${ }^{6}$ Re Mugabe, ILDC 96 (UK 2004), 14 January 2004, Bow Street Magistrate's Court.

${ }^{7}$ Application for a Warrant for the Arrest and Extradition of Robert Gabriel Mugabe, President of the Republic of Zimbabwe, on charges of Torture under Sec. 134 of the Criminal Justice Act 1988, Before Bow Street Magistrate's Court, 7 and 14 January 2004, Decision of Judge Timothy Workman, 14 January 2004. For details on Mugabe case in England, see, D.R. Higgins, Themes and Theories: Selected Essays, Speeches, and Writings in International Law, Vol. I, (Oxford: Oxford University Press, 2009) 418.

${ }^{8}$ Tachiona $v$ Mugabe, 169 F.Supp.2d 259, 309 (S.D.N.Y.2001). But, see generally, the opposition submission in the Brief for the United States, in Tachiona, On her own behalf and on behalf of her late Husband Tapfuma Chiminya Tachiona, et.al; Petitioners v United States of America, On Petition for a Writ of Certiorari to the United States Court of Appeals for the Second Circuit, In the Supreme Court of the United States, No.05-879, April 2006 (in note 9 of the Brief).

${ }^{9}$ Obiang Nguema and others, 23 December 1998, Audiencia Nacional (Central Examining Magistrate No.5).
} 
Nacional saved President Paul Kagame of Rwanda by rejecting a case against him on the ground of immunity from prosecution of a state official. ${ }^{10}$ In February 2008, a Spanish Judge, Fernando Andreu, issued international arrest warrants against 40 senior Rwandan state officials for crimes allegedly committed in 1994. On 23 December 1998, the Audiencia Nacional rejected a complaint against the Moroccan state official Hassan II again on the basis of his immunity from prosecution. ${ }^{11}$

Authorities in Belgium have also indicted several African state officials, at least before an amendment to the Belgian Code of Criminal Procedure that was introduced on 5 August 2003. For example, complaints were filed by private individuals against President Laurent Gbagbo of Ivory Coast; President Denis Sassou Nguesso of Congo; President Paul Kagame of Rwanda and President Ange-Felix Patasse of the Central African Republic. ${ }^{12}$ The former President of Chad, Hissène Habré, was indicted in Belgium on the strength of the passive nationality principle. The case against Habré will be discussed extensively at a later stage in this article, since it is argued that it paved the way to the idea of establishing an African Criminal Chamber.

The case against Abdulaye Yerodia Ndombasi, former Minister of Foreign Affairs of the Democratic Republic of the Congo (DRC), ${ }^{13}$ attracted special attention by African states. At the time of his indictment and issuance of an arrest warrant by Belgium, $\mathrm{Mr}$ Ndombasi was a serving Minister of Foreign Affairs. Ndombasi's case resulted in diplomatic tensions between the DRC and Belgium, and led to the bringing of proceedings by the DRC against Belgium before the ICJ. ${ }^{14}$ The ICJ held that $\mathrm{Mr}$ Ndombasi enjoyed immunity from prosecution under customary international law on the ground that he was a serving minister. It required Belgium to terminate criminal proceedings, cancel the arrest warrant issued against Yerodia, and to inform the authorities to whom it had been circulated. ${ }^{15}$ It should be noted that the ICJ judgment in

\footnotetext{
${ }^{10}$ Rwanda, 6 February 2008, Audiencia Nacional (Central Examining Magistrate No.4).

${ }^{11}$ Hassan II, 23 December 1998, Audiencia Nacional (Central Examining Magistrate No.5).

${ }^{12}$ For a detailed survey of indictments against African state officials, see The African Union-European Union Expert Report on the Principle of Universal Jurisdiction, Council of the European Union, Brussels, 16 April 2009, 8672/1/09, REV 1, at 24-29.

${ }^{13}$ Public Prosecutor v Abdulaye Yerodia Ndombasi, 16 April 2002, Court of Appeal of Brussels, Belgium.

14 The Case Concerning the Arrest Warrant of 11 April 2000 (Democratic Republic of the Congo $v$ Belgium), Judgment of 14 February 2002, ICJ Reports (2002) 3.

${ }^{15}$ Ibid., $\$ \S 59$ and 76.
} 
this case has attracted scholarly criticism. ${ }^{16}$ Much of the criticism lies in the fact that the ICJ failed to uphold Belgium's argument that customary international law requires states to prosecute individuals who commit international crimes, regardless of their official position. Other disagreement is based on the existence of a customary and conventional international law duty of states to prosecute and punish individuals who commit international crimes, which sometimes translates into a state's application of the principle of universal jurisdiction (as Belgium did when it indicted Mr Ndombasi). It should also be noted that some judges of the ICJ have questioned the real reason behind prosecuting African state officials in Europe. If considered carefully, the Separate Opinions of Judges Rezek and Bula-Bula in the Arrest Warrant case $^{17}$ may have had an influence on an African revolutionary idea against prosecution of African state officials in European jurisdictions.

Following the ICJ judgment in the Arrest Warrant case, the Brussels Court of Appeal held in the cases of Ndombasi and Laurent Gbagbo that such cases would be decided only if the alleged perpetrators could be found on Belgian territory. Short of this requirement, no criminal prosecution can take place in Belgium. ${ }^{18}$ In addition, Article 7 of the Belgian Law on international crimes was amended and replaced by the Law of 23 April 2003. According to Bedi, 'the said article did not contain any filter and the law was further made "user-friendly" by the combination of its progressive features with the procedural instrument. Now under the new Article 7(1), the possibility of a complaint would no longer be available for those international crimes which have no connection at all with Belgium. ${ }^{19}$ Hence, if (i) the crime has not been committed in Belgium, (ii) the suspect is not a Belgian national, or (iii) the suspect is not found on Belgian territory, or

\footnotetext{
${ }^{16}$ A. Cassese, 'When May Senior State Officials be tried for International Crimes? Some Comments on the Congo v Belgium Case', 13 European Journal of International Law (2002) 855; J.J. Wouters, 'The Judgment of the International Court of Justice in the Arrest Warrant Case; Some Critical Remarks' 16 Leiden Journal of International Law (2003) 265; S.R.S. Bedi, The Developments of the Human Rights Law by the Judges of the International Court of Justice (Oxford/Portland: Hart Publishers, 2007) 229, at 235 et seq.; D.S. Koller 'Immunities of Foreign Ministers: Paragraph 61 of the Yerodia Judgment as it pertains to the Security Council and International Criminal Court' 20 American University International Law Review (2004) 7; R.V. Alebeek, The Immunity of States and their Officials in International Criminal Law and International Human Rights Law (Oxford: OUP, 2008), 246; W.A. Schabas, An Introduction to the International Criminal Court ( ${ }^{\text {rd }}$ edn., Cambridge: Cambridge University Press, 2007) 231-232.

${ }^{17}$ Separate Opinion of Judge Rezek, Arrest Warrant case, ICJ Reports (2002), §§ 8 and 9; Separate Opinion of Judge Ad Hoc Bula-Bula, Arrest Warrant case, ICJ Reports (2002), §§ 80 and 97.

${ }^{18}$ Bedi, supra note 16 , at 255-256.

${ }^{19}$ Ibid.
} 
(iv) the victim is not a Belgian citizen or has not been residing in Belgium at least three years, only the Federal Public Prosecutor can commence the criminal prosecution. ${ }^{20}$ It is observed that, in Belgium, proceedings against the above mentioned African state officials were terminated on the basis of the immunity of state officials, and of course, due to the amendment of the law requiring, amongst other things, the nationality link between Belgium and the alleged victims of international crimes.

On 5 December 2001, a Prosecutor of the Paris Tribunal de grande instance indicted Congolese senior officials alleging crimes against humanity and torture committed in the Congo against individuals having Congolese nationality. The indictments were against His Excellency Mr. Denis Sassou Nguesso, President of the Republic of the Congo, His Excellency General Pierre Oba, Minister of the Interior, Public Security and Territorial Administration, General Norbert Dabira, InspectorGeneral of the Congolese Armed Forces, and General Blaise Adoua, Commander of the Presidential Guard. ${ }^{21}$ General Norbert Dabira, who had been in France, was held in custody and summoned on 11 September 2002 to be placed under judicial examination. Following the indictment and summons, the Republic of Congo instituted proceedings against France before the ICJ alleging the violation of international law principles governing state sovereignty, the dignity of the state of Congo, and the immunity of the Congolese state officials. The ICJ decided in favour of the Congo, relying on the notion of state sovereignty and immunity of its state officials.

A majority of the cases in European jurisdictions have thus been terminated on different grounds, including the immunity of serving state officials under customary international law and national laws. After having examined the above-mentioned cases, we turn to address the case against the former Chadian president, Hissène Habré, which deserves special attention.

\footnotetext{
${ }^{20}$ Ibid.

${ }^{21}$ Case Concerning Certain Criminal Proceedings in France (Republic of the Congo v France), Request for the Indication of a Provisional Measure, Order of 17 June 2003, ICJ Reports (2003) § 10.
} 
2. The Hissène Habré Case and the Road to the Criminal Chamber in the African Court

When Habré was indicted in Belgium for crimes against humanity, particularly torture, Senegal did not accept to honour its extradition obligation with Belgium. Instead, Senegal approached the AU on this matter. Consequently, the AU mandated Senegal to try Habré before its own domestic courts, acting in the interests of the AU. ${ }^{22}$ The central purpose was to avoid Habré's trial in Belgium. The AU at its meeting in Sudan had asked a Committee of Eminent African Jurists to study the issue of the Belgian extradition request and recommend how to deal with Habré's case, and future international crimes in the continent. ${ }^{23}$ The position stated by the Committee of Eminent African Jurists is examined below.

\section{The influence of the Report of the Committee of Eminent African Jurists} on the Hissène Habré Case on the Proposed Criminal Chamber

It is important to know that even before the 2009 AU decision to establish a Criminal Chamber with jurisdiction to try international crimes, the origin of an African idea or priority to prosecute international crimes in Africa had begun in $2006 .{ }^{24}$ In January 2006, at Khartoum, Sudan, the Summit of the AU Heads of state and governments decided to set up a Committee of Eminent African Jurists on the Case of Hissène Habré (the Committee). ${ }^{25}$ This Committee was appointed to study and consider all aspects and implications of the Habré case in Senegal or Belgium. It was specifically instructed to take into account the following factors: ${ }^{26}$

(a) Adherence to the principle of total rejection of impunity;

\footnotetext{
${ }^{22}$ At its meeting in July 2006 at Banjul, The Gambia, the AU took a decision mandating the Republic of Senegal to 'prosecute and ensure that Hissène Habré is tried, on behalf of Africa, by a competent Senegalese Court with guarantees of fair trial.' Decision Assembly/ AU/Dec.127 (VII), (Doc. Assembly/AU/3 (VII)).

${ }^{23}$ Report of the Committee of Eminent African Jurists on the Case of Hissène Habré, submitted to the Assembly of the African Union, Ordinary Session, July 2006, available at http://www.africa-union.org (visited 20 October 2010).

${ }^{24}$ However, see M.K. Hansungule, 'The African Charter on Human and Peoples' Rights: A Critical Review', African Yearbook of International Law (2000), at 269-270, note 8 thereof.

${ }^{25}$ See Assembly/AU/ Dec. 103 (VI), January 2006, at Khartoum, Sudan.

${ }^{26}$ Supra note $23, \S 1$.
} 
(b) Adherence to international fair trial standards including the independence of the judiciary and impartiality of proceedings;

(c) Jurisdiction over the alleged crimes for which Mr. Habre should be tried;

(d) Efficiency in terms of cost and time allocated to trial;

(e) Accessibility to the trial by alleged victims as well as witnesses;

(f) Priority of an African mechanism.

Additionally, the Committee was mandated to make concrete recommendations on the above mentioned matters, suggest ways or means to deal with issues of similar nature in the future, and to submit its report to the Ordinary Session of the AU Assembly in July, 2006. ${ }^{27}$ The Committee met at Addis Ababa, Ethiopia, from 22 to 24 May 2006 and considered the specific case of Habre and what was to be done for the future in Africa in respect of international crimes involving African personalities. In particular, the Committee designed a mechanism to deal with impunity in Africa, thereby rejecting it. ${ }^{28}$

Regarding immunity from prosecution for international crimes, the Committee considered that 'Hissène Habré cannot shield behind the immunity of a former Head of State to defeat the principle of total rejection of impunity ${ }^{29}$ in Africa. The Committee's position was in line with the legal positions stated in the cases involving Augusto Pinochet and Charles Taylor. The Committee's stand represented a milestone in the development of international criminal law in Africa, particularly on immunity from prosecution for international crimes. Equally, the Committee had considered that, given the nature and gravity of the crimes with which he was charged, Habre could not benefit from the statutes of limitations. ${ }^{30}$

As regards the African solution to Habré's trial, the Committee also considered the question of jurisdiction to try him. It held that both Chad and Senegal had the necessary jurisdictional links to the Habré case. Moreover, both states had ratified the 1984 Convention against Torture (CAT). The Committee suggested that since Habré was within the territory of Senegal, Senegal had jurisdiction to try him on the strength of the principle of territorial jurisdiction and on account of the fact that it was a state party to

\footnotetext{
${ }^{27}$ Ibid., $\S 2$.

${ }^{28}$ Ibid., $\S \S 8--9,12$

${ }^{29} \mathrm{Ibid}$., $\$ 13$.

${ }^{30}$ Ibid., § 14.
} 
the Convention against Torture. To some extent, the Committee's decision was informed by the decision of the United Nations Committee against Torture of 17 May 2006, concerning Habré. This decision declared that, by granting asylum to Habré and by not extraditing him to Belgium, Senegal violated Articles 5(2) and 7 of the Convention against Torture. Therefore, it was upon Senegal to respect its international obligations, namely by taking steps to bring Habré to trial for torture committed in Chad. ${ }^{31}$ Thus, if Senegal were to try Habré, it was necessary for the state to confer special powers to its courts to try him. Regarding Chad, the Committee reasoned that Chad, by virtue of Article 5(1) of the Convention Against Torture, would be entitled to exercise jurisdiction over Habré by asking for his extradition from Senegal. ${ }^{32}$ This conclusion was grounded on several considerations. First, Chad was Habré's state of nationality (active nationality principle), and Habré was a former President of Chad. In addition, the acts of torture with which Habré was charged were committed in Chad. Finally, victims were mostly Chadian nationals.

The Committee did not end with Senegal or Chad in respect of jurisdiction. It also considered the feasibility of establishing an ad hoc Tribunal to try Habré for torture committed in Chad. It reasoned that the power of the AU Assembly to set up such Tribunal would arise from the provisions of Articles 3(h), 4(h), 4(o), 9(1) (d) and 5(1) (d) of the Constitutive Act of the African Union (2000). ${ }^{33}$ These provisions reject impunity for the crimes of genocide, crimes against humanity and war crimes in Africa.

Regarding regional jurisdiction to try Habré, the Committee considered the African Court on Human and Peoples' Rights and the African Court of Justice. It concluded that, at that time, the two courts did not have jurisdiction to try those responsible for international crimes in Africa, however gross the human rights violations may have been. Therefore, according to the Committee, the 'two institutions [could not] hear the Habré case'. 34

\footnotetext{
${ }^{31}$ Communication No. 181/2001, Suleymane Guengueng et al v Senegal, Decision of the Committee against Torture under Article 22 of the Convention against Torture and Other Cruel, Inhuman or Degrading Treatment or Punishment, Thirty-sixth session, CAT/C/36/D/181/2001, 19 May 2006. The Committee found Senegal in violation of Articles 5(2) and 7 of the Convention Against Torture because Senegal had failed to prosecute Hissene Habre or prosecute him to Belgium to face criminal prosecution.

${ }^{32}$ Supra note $23, \S 20$.

${ }^{33}$ Supra note $23, \S 22-25$.

${ }^{34}$ Supra note $23, \S 26$.
} 
Consequently, the Committee recommended that an 'African solution' should be opted for, and that Habré should be tried by an African state, giving Senegal and Chad first preference. ${ }^{35}$ More importantly, the Committee also tackled the issue of how African states should deal with similar crimes in the future. It held that it was necessary to send the signal to African states that impunity is intolerable and no longer an option for Africa. In this connection, the Committee observed 'the possibility of conferring criminal jurisdiction on the African Court of Justice [to confer criminal competence that can be adopted by States within a reasonable time-frame], to make the respect for human rights at national, regional and continental levels a fundamental tenet for African governance. 36

Besides, the Committee observed that there was need for an African Court on Human and Peoples' Rights to be conferred criminal jurisdiction to try international crimes in Africa. In the Committee's view, 'there is room in the Rome Statute for such a development and that it would not be a duplication of the work of the International Criminal Court. ${ }^{37}$ The Committee had in mind the issue of complementarity under Articles 1 and 17 of the Rome Statute and paragraph 10 of the Preamble thereto. Arguably, the Rome Statute only envisages national criminal jurisdictions and not regional or sub-regional criminal jurisdictions insofar as the question of complementarity is concerned. It may be further argued that the mere existence of the ICC does not preclude the establishment of regional courts such as the Criminal Chamber. Such institution can co-exist in parallel with the ICC because, hierarchically, the Criminal Chamber may not be subservient to the ICC.

Since the Committee had reasoned in line with the idea to establish a single court in Africa ('the African Court of Justice and Human and Peoples' Rights', a merged African court), in its recommendations the Committee stressed that 'the African Court should be granted jurisdiction to try criminal cases.' The Committee further 'recommend[ed] that the text [of the African Court] should be adopted through the quickest procedures possible. ${ }^{38}$ It called for the independence and impartiality of such a

\footnotetext{
${ }^{35}$ Supra note $23, \S \S 27-30$.

${ }^{36}$ Supra note $23, \S 34$.

${ }^{37}$ Supra note $23, \S 35$.

${ }^{38}$ Supra note $23, \S 39$.
} 
court, and for a rapid response mechanism to ensure that Africa acts with dispatch in situations of gross human rights violations. ${ }^{39}$

Based on the recommendations of the Committee, the AU decided that Senegal should try Habré on behalf of Africa. Hence, at its July 2006 meeting in Banjul, The Gambia, the AU mandated Senegal to "prosecute and ensure that Hissène Habré is tried, on behalf of Africa, by a competent Senegalese Court with guarantees of fair trial. ${ }^{40}$ To comply with this mandate, 'Senegal amended its constitution to allow its courts to prosecute grave crimes [crimes against humanity] committed in the past and outside its territories. ${ }^{41}$ To give effect to the duty to prosecute and punish Habré under the Convention against Torture, to which it is a state party, Senegal then amended its Penal Code to include new crimes of genocide, crimes against humanity and war crimes. Also, Senegal amended its Code of Criminal Procedure to enable its courts to exercise universal jurisdiction over such crimes, even if committed in the past and in a foreign territory. ${ }^{42}$ On 23 July 2008, Senegalese legislative chambers adopted a law amending the Constitution of Senegal and authorising 'retroactive application of its criminal laws, with a view to trying exclusively and solely Mr. Hisséne Habré. ${ }^{43}$ The idea was to enable prosecution of Habré in Senegal for his past crimes committed in Chad. This step followed the trial of Habré in 2005, when the Senegalese court had ruled that Senegal did not have jurisdiction to try him for crimes committed outside its territory and that Senegal had no law at that time to implement the Convention against Torture. ${ }^{44}$ Equally, the

\footnotetext{
${ }^{39}$ Supra note $23, \S \S 40-41$.

${ }^{40}$ Decision Assembly/ AU/Dec.127 (VII), (Doc. Assembly/AU/3 (VII)).

41 C.S. Igwe, 'The ICC's favourite Customer: Africa and International Criminal Law', XL The Comparative and International Law Journal of Southern Africa (2008) 294, at 314; J. Pejic, 'Accountability for International Crimes: From Conjencture to Reality', 84 International Review of the Red Cross (March, 2002), at 24-25; M. Inazumi, Universal Jurisdiction in Modern International Law: Expansion of National Jurisdiction for Prosecuting Serious Crimes under International Law (Antwerpen/Oxford: Intersentia, 2005), 90-91.

${ }^{42}$ Case Concerning Questions Relating to the Obligation to Prosecute or Extradite (Belgium v Senegal), Request for the Indication of Provisional Measures, Order of 28 May 2009, ICJ General List No.144, § 6; In the Matter of Michelot Yogogombaye $v$ The Republic of Senegal, Application No. 001/2008, African Court on Human and Peoples' Rights, Judgment, 15 December 2009, § 20.

${ }^{43}$ Yogogombaye v Senegal, ibid., § 20.

${ }^{44}$ In 2000 and 2005, Senegalese courts ruled that they did not have jurisdiction to prosecute Habré for crimes committed in Chad contending that there was no law in Senegal that allowed them to do so, and that Habre enjoyed functional immunity for acts of torture in Chad whilst he was still in power.
} 
Senegalese Court of Appeal had also held that it had no jurisdiction on extradition requests by Belgium over Habre. ${ }^{45}$

Thanks to the AU decision and its own efforts to try Habré in its domestic courts, Senegal has avoided enforcing the international arrest warrant issued by a Belgian court against Habré. However, to date, Senegal has not put Habré on trial because of alleged financial difficulties. This is now the reason why Belgium has instituted proceedings before the ICJ against Senegal. ${ }^{46}$ The Case Concerning Questions Relating to the Obligation to Prosecute or Extradite (Belgium v Senegal) ${ }^{47}$ touches on the immunity of a former head of state of Chad, Mr. Habré, at least in respect of his extradition from Senegal to Belgium. In this case, Senegal argued that its courts had ruled that, amongst other reasons, Habré's official capacity as former president of Chad had acted as a barrier to allow his extradition to Belgium to face criminal prosecution for torture and crimes against humanity. It is submitted that Senegal's contention is contrary to international law governing extradition of perpetrators of international crimes ${ }^{48}$ because immunity of state officials is no longer a valid defence for the commission of international crimes. ${ }^{49}$

Apart from the discussion on the AU and the Habré case, it is important to note the joint study on universal jurisdiction carried out by the AU and European Union (EU). This study has a bearing on the concerns raised by the AU that domestic courts in Europe have selectively indicted or prosecuted African state officials on the basis of universal jurisdiction. $^{50}$

After the long term factors discussed above, the article now turns to explore the immediate factor that has triggered an expeditious process to put the Criminal Chamber in place.

\footnotetext{
45 Igwe, supra note 41 , at 313.

${ }^{46}$ Belgium v Senegal, supra note 42, § 7.

${ }^{47}$ Ibid.

${ }^{48}$ See Arts 5(2) and 7 Convention Against Torture, 1984.

${ }^{49}$ Art 27 ICCSt., adopted in 1998, outlaws immunity of state officials.

${ }^{50}$ See, The AU-EU Expert Report on the Principle of Universal Jurisdiction, Council of European Union, 8672/1/09, REV 1, Brussels, 16 April 2009, §§ 34-38 and 46.
} 


\section{B. The Immediate Factor for the Establishment of the Criminal Chamber}

1. The International Criminal Court and Prosecution of International Crimes in Africa

Cases currently pending before the ICC are all from Africa. Based on the state referrals and referrals by the United Nations Security Council, ${ }^{51}$ and holding that there were reasonable grounds to believe that individuals had committed international crimes in Uganda, the DRC, Central African Republic and Darfur, Kenya and Libya, the ICC Prosecutor requested the Pre-Trial Chambers to issue warrants of arrest for various individuals, including the President of Sudan, Omar Hassan Al-Bashir, Muammar Gaddafi of Libya, the three Kenyan state officials charged before the ICC, and former president Laurent Gbagbo of Ivory Coast, currently under investigation by the ICC Prosecutor. As of October 2011, seven situations are before the ICC, which have led to several cases. For the sake of brevity, these cases will not be discussed at length here. Significantly, the ICC has gone a step further in indicting the current president of Sudan and the deposed leader of Libya, Muammar Gaddafi (died on 20 October 2011) despite the fact that Sudan and Libya are not states parties to the Rome Statute. However, none of the cases has been completed yet; they are all pending.

Let us now focus on the situation in the Darfur region of Sudan. The AU maintains that the search for justice should be pursued in a way that does not impede or jeopardize the promotion of peace in Sudan. ${ }^{52}$ The AU feels that 'the process initiated by the ICC and the decision of its Pre-Trial Chamber have the potential to seriously undermine the on-going efforts to address the many pressing peace and security challenges facing Sudan and may lead to further suffering for the people of the Sudan and greater destabilization of the country and the region. ${ }^{53}$ The AU requested the United Nations Security Council to defer the investigation in respect of the Darfur situation, but the United Nations has not accepted. ${ }^{54}$ The AU's position is stated in its decision on the

\footnotetext{
${ }^{51}$ State referrals and referrals by the Security Council are governed by Art 13 ICCSt.

${ }^{52}$ Communique of the $175^{\text {th }}$ meeting of the Peace and Security Council of the African Union, 5 March 2009, PSC/PR/Comm (CLXXV), Addis Ababa, Ethiopia, § 2.

${ }^{53}$ Ibid., § 4.

${ }^{54}$ Decision on the Application by the International Criminal Court (ICC) Prosecutor for the Indictment of the President of the Republic of Sudan, Decision Assembly/AU/Dec.221 (XII), Adopted by the Assembly of the AU at Sirte, Libya, on 3 July 2009, § 3.
} 
ICC adopted on 3 July 2009 at Sirte, Libya. ${ }^{55}$ The AU cautioned that, in view of the 'delicate nature of the peace processes' underway at the time in Sudan, the approval by the Pre-Trial Chamber of the ICC on the application for the issuance of arrest warrant against President Bashir would 'seriously undermine the ongoing efforts' aimed at facilitating peace in Darfur. ${ }^{56}$ The AU Assembly went a step further and requested the Commission of the African Union to discuss the issue of indictments against African leaders. It requested the AU Commission

to convene as early as possible, a meeting of the African countries that are parties to the Rome Statute on the establishment of the International Criminal Court (ICC) to exchange views on the work of the ICC in relation to Africa, in particular in the light of the processes initiated against African personalities, and to submit recommendations thereon taking into account all relevant elements. $^{57}$

Having known that the Security Council has not accepted to defer investigation of President Bashir of Sudan, the AU has emphatically decided not to cooperate with the ICC:

[The AU Assembly] decides that in view of the fact that the request by the African Union has never been acted upon, the AU member states shall not cooperate pursuant to the provisions of Article 98 of the Rome Statute of the ICC relating to immunities, for the arrest and surrender of President Bashir. $^{58}$

It is apparent that the $\mathrm{AU}$ contends that, whilst it does not tolerate impunity ${ }^{59}$ it is nevertheless, concerned with the indictment and warrant of arrest issued by the ICC against President Bashir. It seems that arresting and possibly prosecuting President Bashir would disrupt the peace process in Darfur. ${ }^{60}$ In this regard, it appears that President Bashir is needed for the peace process in the region. The AU has also taken the same position against the prosecution of Colonel Muammar Gaddafi of Libya and the three Kenyan officials charged with international crimes before the ICC. At its summit on 30 June and 1 July 2011, at Malabo, Equatorial Guinea, by its Decision Assembly AU/Dec. 363 - 390 (XVII), the AU decided that member states of the African Union shall not

\footnotetext{
${ }^{55}$ Ibid.

${ }^{56}$ Supra note $55, \S 2$.

${ }^{57}$ Supra note 55, § 5.

${ }^{58}$ Supra note $55, \S 10$

${ }^{59}$ Supra note $55, \S 6$.

${ }^{60}$ Supra note 55, §§ 2-3.
} 
cooperate with the ICC in the execution of the warrant of arrest issued for Colonel Muammar Gaddafi of Libya, contending that the warrant complicates efforts aimed at a negotiated political solution in Libya. The AU called on the United Nations Security Council to activate the provisions of article 16 of the ICC Statute with a view to deferring the investigation and prosecutions in the situation in Libya in the interest of justice and peace in Libya. As already observed above in the introduction to this article, the AU also requested the African Commission to actively pursue the implementation of the $\mathrm{AU}$ Assembly decisions on the African Court being empowered to try serious international crimes committed on African soil.

In conclusion, it is the AU's decisions not to cooperate with the ICC that has led to the call for establishment of a Criminal Chamber within the African Court to prosecute African individuals who commit international crimes in Africa. The following parts of this article will examine the proposed Criminal Chamber. The AU is determined to prosecute African individuals, including state officials who commit international crimes in Africa. However, not before the ICC. The AU seems to suggest that the establishment of the Criminal Chamber within the African Court is the only possible way to address impunity in Africa through an African mechanism or solution - whereby African state officials who commit international crimes in Africa - may be judged by their fellow Africans in Africa. The following paragraphs will now discuss this dramatic attempt in Africa.

\section{Is the Establishment of the Criminal Chamber a Solution?}

The African states seem to contend that since the ICC is targeting African leaders, such as President Bashir of Sudan, Colonel Muammar Gaddafi of Libya and the three Kenyan state officials charged before the ICC, and Laurent Gbagbo of Ivory Coast, they want to establish an African court as an alternative for their own leaders to avoid prosecutions before the ICC. There is a perception that the prospective Criminal Chamber may work for Africa, at least hypothetically. It would serve as an African solution to African endemic problems of international crimes and gross violations of human rights. However, it remains to be seen whether the prospective Criminal Chamber will work efficiently. 
Indeed, if it is necessary that Africa punishes perpetrators of international crimes in house, institutional frameworks in a form of the Criminal Chamber ${ }^{61}$ must be set up to do so, and the relevant court or Criminal Chamber should be enhanced both in terms of capacity and legal support. Judicial independence should be a prerequisite for the dispensation of justice in Africa. Even where the Criminal Chamber might be established, the political commitment of the $\mathrm{AU}$ is vital to achieve the demands of justice for Africans. Furthermore, to enforce and provide cooperation with the Criminal Chamber, the African Union should ideally adopt a treaty to guarantee its commitment to cooperate with the proposed Criminal Chamber.

\section{Legality and Grounds for the Establishment of the Criminal Chamber}

African states have been empowered by Article 4(h) of the Constitutive Act of the AU to take measures to prevent the commission of international crimes, especially in situations of grave concern such as the commission of genocide, war crimes and crimes against humanity, given that these crimes pose a threat to peace and security. It can thus be contended that Article 4(h) of the Constitutive Act of the AU may be the legal basis for the establishment of the 'Criminal Chamber' in the proposed merger of the African Court of Justice and Human Rights. Besides, decisions of the AU are more express on the mandate to establish the Criminal Chamber. ${ }^{62}$

The effect of the AU decision Assembly/AU/Dec.221 (XII) and Decision Assembly AU/Dec. 363 - 390 (XVII) will be the adoption of a Protocol with a view to establishing a Criminal Chamber within the merged African Court of Justice and Human Rights, thereby giving it jurisdiction to try international crimes committed in Africa. In 2009, the African Commission of the African Union (AU Commission) in consultation with the African Commission on Human and Peoples' Rights (African Commission), and the African Court on Human and Peoples' Rights, undertook a study to examine the implications of the Criminal Chamber of the African Court of Justice and Human Rights

\footnotetext{
${ }^{61}$ This possibility has already been debated by the African Union through its resolution on the ICC, adopted on 3 July 2009 at Sirte, Libya, supra note 55, § 5.

${ }^{62}$ Supra note 55.
} 
to try international crimes in the continent. ${ }^{63}$ A report on the study was submitted to the Assembly of the AU in July 2010. ${ }^{64}$ As observed before, there is a Draft Protocol on the Amendments to the Protocol on the Statute of the African Court of Justice and Human Rights, which was discussed by key stakeholders at two workshops in August and November 2010, held at Midrand, South Africa. The Draft Protocol will be submitted by the AU Commission for adoption by the AU Assembly in 2012. If the Protocol will be adopted in 2012, it will constitute a legal basis for the proposed Criminal Chamber.

However, one should also enquire the following: does the proposed Criminal Chamber have a legal basis under the ICC Statute? It will be recalled that Articles 1 and 17 of the Rome Statute of the ICC deal with the complementarity principle. The Rome Statute does not expressly allow or even imply that regional courts such as the proposed Criminal Chamber be conferred with jurisdiction to try international crimes that are under the jurisdiction of the ICC. ${ }^{65}$ Can it be contended that regional courts have jurisdiction to try international crimes, by analogy with national courts? In this author's view, the clear position of the Rome Statute is to confer jurisdiction over international crimes on national courts. Nevertheless, a progressive interpretation of positive complementarity might, for the purposes of closing all impunity gaps, infer that even regional criminal courts could have jurisdiction over international crimes within the ICC jurisdiction.

Although it can be argued that the establishment of the proposed Criminal Chamber will not compete with the ICC in terms of jurisdiction, from the reading of the Rome Statute it is difficult to establish a clear legal basis for the proposed Criminal Chamber.

A distinction should be made, however, for the crime of genocide. Article VI of the Genocide Convention empowers international penal tribunals (which would be

\footnotetext{
${ }^{63}$ Decision Assembly/AU/Dec.213 (XII), Adopted by the Assembly of the AU at its $12^{\text {th }}$ Ordinary Session held in Addis Ababa, Ethiopia from 1-3 February 2009, § 9.

${ }^{64}$ By Decision Assembly/AU/Dec.213 (XII), § 9, the AU Assembly had requested the Commission, in consultation with the African Commission on Human and Peoples' Rights, and the African Court on Human and Peoples' Rights, 'to examine the implications of the Court being empowered to try international crimes such as genocide, crimes against humanity, and war crimes and report thereon to the Assembly in 2010.'

${ }^{65}$ The assumption of the present paper is that the 'ICC system' as a whole foresees a dichotomy (domestic prosecution or prosecution by the ICC), in which a third layer - a regional criminal court — is not provided for.
} 
interpreted to include regional criminal courts, such as the proposed Criminal Chamber) to prosecute and punish individuals who commit genocide. Therefore, if the proposed Criminal Chamber is to be established in Africa, the legal basis will be Article VI of the Genocide Convention (with respect to genocide) as well as Articles 4(h), 4(m) and 4(o) of the Constitutive Act of the AU (regarding crimes against humanity, war crimes and genocide). Although Article 4(h) above talks about intervention in respect of grave circumstances of international crimes, it is argued that the intervention envisaged under Article 4(h) of the Constitutive Act of the AU is military intervention (use of force) but not judicial intervention, such as prosecution of such crimes. If Article 4(h) above is to be of any aid, it must be by analogy only. Perhaps a further strong basis may be customary international law, which requires states to prosecute and punish the perpetrators of international crimes.

\section{A. How should the Criminal Chamber Treat Immunity of State Officials?}

The legal instrument that will establish the Criminal Chamber within the African Court should provide in a more express way that immunity must not be a defence or a mitigating factor in the prosecution and punishment of individuals who commit international crimes in Africa. This would be in line with the spirit of the Genocide Convention, and Article 4(m) and (o) of the Constitutive Act of the AU, Article 27 of the Rome Statute as well as Article 12 of the Protocol for the Prevention and the Punishment of the Crime of Genocide, War Crimes and Crimes against Humanity and all forms of Discrimination (of the Great Lakes Region). Equally, the founding instrument should allow the court to issue subpoenas against individuals, including state officials whenever there are grounds to link them with the commission of international crimes. If no provision is expressly intended to outlaw immunity attaching to African state officials, there is no way impunity would be expressly addressed even by establishing a Criminal Chamber in Africa. In such case, it would be moot and irrelevant to establish the Criminal Chamber while knowing that the ICC can prosecute and punish individuals, including state officials who commit international crimes. However, if no express provision outlaws immunity and rejects statutes of limitation for international crimes under the proposed Criminal Chamber, recourse should be had to customary international 
law and conventional international norms or principles outlawing immunity for international crimes.

\section{B. If the Criminal Chamber is Established, What Are the Likely Problems?}

Although the establishment of the Criminal Chamber is practically feasible, and is a milestone for Africa, arguably such an institution will nevertheless be subject to the lack of political will from African states to make it become more effective ${ }^{66}$ If the proposed Criminal Chamber comes into existence, there are many concerns.

First, it is not quite likely that the proposed Criminal Chamber will effectively exercise its jurisdiction over international crimes in Africa freely. Prosecuting and punishing international crimes is not an easy task. It is most likely that such prosecution and punishment will involve senior state officials and military commanders in Africa. International crimes lead to more politically sensitive cases in states, particularly in Africa. In this continent, peace and security are at the hands of heads of state. Suppose a sitting head of state is implicated in the commission of international crimes, such as is the case with President Omar Al-Bashir of Sudan, it is inevitable that there would be claims of fragile peace and security in such country if the head of state is indicted or prosecuted. These concerns have already been expressed over the arrest of President Omar Al Bashir of Sudan. The AU has cited security concerns in its decisions not to cooperate with the ICC over the arrest warrant against President Omar Al- Bashir. ${ }^{67}$

Omar Al Bashir is allegedly implicated in the international crimes committed in Darfur. Would any African state enforce an arrest warrant issued by the proposed Criminal Chamber? Can any African state arrest sitting presidents of other African states even if there may be clear indications of commission of international crimes? In this author's view, it does not seem to be practicable, or even possible, for an African state to arrest a sitting state official from another African country because of the deep-rooted

\footnotetext{
${ }^{66}$ Some of these problems have already been pointed out authorities in Africa; see T.B. Nyanduga, 'Reflections and Perspectives of the African Commission on Human and Peoples' Rights', Paper presented at a Consultative Conference on International Criminal Justice, 'Regional Courts and Commissions', 9-11 September 2009, United Nations Headquarters, New York., at 1-8.

${ }^{67}$ See concerns raised by the Peace and Security Council of the AU in its Communique of the $175^{\text {th }}$ meeting, 5 March 2009, supra note 54, §§ 1-2; Decision Assembly/AU/Dec.221 (XII), supra note 55, § 2.
} 
principle of non-interference in internal affairs in Africa. To give a practical example, it is evident that the AU has openly condemned the ICC for reporting its concerns to the United Nations Security Council that Kenya, Djibouti, Malawi and Chad failed to respect their obligations under the Rome Statute by failing to arrest Omar Al Bashir. ${ }^{68}$ This is notwithstanding the provisions of Article 4(o) of the Constitutive Act of the AU rejecting impunity and articles 86 - 93 of the Rome Statute imposing obligations on these states to cooperate with the ICC in the investigation and prosecution of persons responsible for international crimes (these states are parties to the Rome Statute). Such obligation includes arresting and surrendering suspects to the ICC. Unless African states enforce Article 4(o) of the Constitutive Act of the AU as well as Article 27 of the Rome Statute and Article 12 of the Protocol for the Prevention and the Punishment of the Crime of Genocide, War Crimes and Crimes against Humanity and all forms of Discrimination (of the Great Lakes Region), there is no way African states may come close to arresting and prosecuting sitting state officials for international crimes in Africa.

The second problem would be how to address the question of universal jurisdiction in relation to international crimes. Some African states, such as Senegal, have persistently refused to observe their obligations in respect of international crimes, especially for individuals like Habré who is alleged to have committed crimes against humanity. There is no indication that African states are fully prepared to abide by their international obligations to punish individuals, including state officials who commit international crimes in Africa. It should be recalled that Senegal's refusal to extradite Habré to Belgium to face criminal prosecution for torture prompted Belgium to institute legal proceedings against Senegal before the ICJ. ${ }^{69}$ Again, when Omar Al Bashir visited

\footnotetext{
${ }^{68}$ The AU, Division of Communication and Information, 'Press Release No 119/2010 on the Decision of the Pre-Trial Chamber of the ICC informing the UN Security Council and Assembly of the State Parties to the Rome Statute about the presence of President Omar Hassan Al-Bashir of the Sudan in the territories of the Republic of Chad and the Republic of Kenya.' (29 August 2010), at 1-2. See also, the 30 June -1 July 2011 AU Assembly Decision on the Implementation of the Assembly Decisions on the International Criminal Court, Assembly AU/Dec. 366(XVII), § 5 where the AU 'Reaffirms that by receiving President Bashir, the Republic of Chad, Kenya and Djibouti were discharging their obligations under Article 23 of the Constitutive Act of the African Union and Article 98 of the Rome Statute as well as acting in pursuit of peace and stability in their respective regions.'

${ }^{69}$ Belgium v Senegal, supra note 42.
} 
Kenya and Malawi, such states failed to apply universal jurisdiction and arrest him despite their obligations under international law. ${ }^{70}$

Furthermore, since the AU as a whole has refused to cooperate with the ICC over the arrest warrant against Omar Bashir, it is not clear whether the AU is prepared to tackle the problem of state leaders who commit international crimes in the continent.

Resource constraints will be another major impediment to the functioning of the Criminal Chamber in Africa. An example is the way African states have failed to honour their financial obligations in respect of the Habré trial in Senegal despite their pledges to contribute funds. ${ }^{71}$ If African states have failed to honour their obligations in respect of one case, how feasible would it be for them to cooperate with the Criminal Chamber? Lack of funds will inevitably hamper the work of the Criminal Chamber. International crimes lead to complex cases that require more resources for investigation, the gathering of evidence and witness testimonies, prosecution and logistical support until the judgment is delivered, and up until the person serves his or her sentence. Resource availability is even further subjected to the political will of the African state leaders, who might be subject of prosecution before the same court they are supposed to finance. If at all the court is to be established, African leaders must be prepared to accept their obligations to allocate resources for the work of the Criminal Chamber.

In other words, while theoretically it is legally feasible, the establishment of an (African) Criminal Chamber would probably be grounded in the unwillingness of African states to effectively cooperate with the Chamber, with a view to achieving fair prosecutions and trials. This 'shield' of sorts from ICC intervention would likely be ineffective and ultimately merely add another layer of complementarity, without effectively heeding the call for an end to impunity.

\footnotetext{
${ }^{70}$ Secs. 8 and 18, International Crimes Act, 2008 (Kenya); under sec 4(1) Geneva Conventions Act (Malawi), courts in Malawi may exercise universal jurisdiction over grave breaches of the Geneva Conventions; article 17, Constitution of Malawi, 1994 prohibits acts of genocide, especially considering that President Omar Al Bashir has been charged with acts of genocide before the ICC.

${ }^{71}$ See, Decision on the Hissène Habré Case, Adopted by the $14^{\text {th }}$ Ordinary Session of the AU Assembly in Addis Ababa, Ethiopia on 2 February 2010, Doc. Assembly (AU/9(XVI), Assembly/AU/Dec.272 (XIV), $\S \S 4-8$; Press Release No. 104, $15^{\text {th }}$ AU Summit, Decisions of the $15^{\text {th }}$ AU Summit' 29 July 2010, Addis Ababa, at 6.
} 


\section{Arguments For and Against the Criminal Chamber}

Despite the problems likely to affect the functioning of the Criminal Chamber, it is not a strange idea to establish such an institution in Africa. There exist courts in Africa such as the International Criminal Tribunal for Rwanda and the Special Court for Sierra Leone. Hence, there is already a trend towards establishing international courts in the continent. Furthermore, as argued before, the fact that the ICC exists does not rule out the possibility that independent and sovereign African states in their collective nature may establish a Criminal Chamber based on (i) international treaties allowing states to prosecute and punish international crimes, ${ }^{72}$ (ii) the Constitutive Act of the AU, and (iii) customary international law. Not all states in Africa are parties to the Rome Statute. So, any argument regarding state cooperation will only bind those states parties to the Rome Statute. Furthermore, since customary international law allows states to punish international crimes, it is necessary that courts be established, whether domestically or at regional and international levels for this purpose.

It would be good for Africa to establish a court which will be close to the African people and which might have access to victims and areas where crimes have been committed. These arguments, however, can only stand if African states are willing to abide by their obligations to cooperate with such a Criminal Chamber. In addition, perhaps it could be good for the Criminal Chamber to show its distinctive features by dealing with the crime of aggression ${ }^{73}$ and certain common crimes in Africa (that do not all amount to international crimes) such as election-rigging, unconstitutional change of governments, human trafficking, acts of terrorism, piracy, drug trafficking, slave practices and slavery. These are crimes over which the ICC cannot exercise jurisdiction at this time. Although the ICC has competence over the crime of aggression, and although the Kampala Review Conference in June 2010 agreed on the definition of this crime, ${ }^{74}$

\footnotetext{
${ }^{72}$ Such treaties include the Convention against Torture, Arts 5(2) and (7); art VI, Genocide Convention, 1948, (1951) 78 UNTS 227.

${ }^{73}$ On the definition of the crime of aggression, see Art. 8 bis ICCSt.

${ }^{74}$ The definition was agreed during the Review Conference of the Rome Statute of the International Criminal Court, held at Kampala, Uganda from 31 May to 11 June 2010; 'Amendments to the Rome Statute of the International Criminal Court' Report of the Working Group on the Crime of Aggression, rc/wgca/1/Rev.2, Annex II, 7; Conference Room Paper on the Crime of Aggression, RC/WGCA/1/REV.2, Draft Resolution on the Crime of Aggression, 7 June 2010, Annex I, at 3, available at http://www.icccpi.int/iccdocs/asp_docs/RC2010/RC-20-ENG-Annex.II.WGCA.report.pdf (visited 19 October 2010).
} 
the ICC cannot proceed against aggression until after the next Review Conference of the Assembly of States Parties to the Rome Statute. Hence, if the Criminal Chamber is established in Africa, the AU will have an opportunity to prove its good will to prosecute the crime of aggression, in addition to other crimes within the jurisdiction of the ICC.

The preceding arguments in support of the Criminal Chamber do not outweigh the arguments against it. Unless the inherent problems associated with the establishment of the Criminal Chamber are addressed more meaningfully, there remains nothing to convince the world and Africans that the proposed Criminal Chamber has any 'genuine' purpose for Africa and the whole international community. It will be recalled that the calls for the establishment of the proposed court have only come after African leaders have been indicted by the ICC and the domestic courts of some European states. Clearly, the indictments of Habré of Chad and President Omar Al Bashir of Sudan triggered calls for the establishment of this Chamber. Why did not the AU establish such a Criminal Chamber in the past? Does Africa have genuine grievances against the ICC or domestic courts of European states? Arguably, calls to establish the Criminal Chamber are simply meant to establish a court that will compete with the ICC in terms of jurisdiction over persons and crimes committed in Africa. There seems to be no convincing argument that can explain why the AU has decided to establish such a Criminal Chamber at present. One wonders how the proposed court will relate to the ICC in terms of prosecution of international crimes. On the face of it, calls for the establishment of the Criminal Chamber are manifestly meant to detract from the progressive development of international criminal justice.

It may also be noted that amongst the arguments for the establishment of the ICC as a permanent court was the fact that international criminal tribunals are costly and many. Hence, there was need for one permanent court. If the AU establishes a Criminal Chamber, it does not seem feasible that African states will be able to meet their financial obligations both to the ICC and the proposed Criminal Chamber. There are obvious reasons for this assertion. Institutions established to monitor and protect human rights in the African continent still suffer from under-budget or severe lack of funding to the extent that reliance on donor finances is unavoidable. If this is the case, how would the 
AU ensure funding for the Criminal Chamber? What is different from the already existing funding mechanisms for human rights institutions in Africa?

It is contended that, although there may be good ideas to protect and respect human rights, Africa is now in a state of confusion, not knowing what to do first. It must be recalled that the African Commission on Human and Peoples' Rights was established to monitor human rights in Africa and issue recommendations against states found to violate human rights. Subsequently, it was felt that there was need to establish an African Court of Justice for the continent. Before the court came into functioning, there was also a parallel idea to establish an African Court on Human and Peoples' Rights. This was followed by an idea to merge the two courts, thereby forming one court: that is, the African Court of Justice and Human Rights. This is already not effectively functional to date as some of the African states have not yet ratified the Protocol establishing this court. $^{75}$ Yet, we now have proposals and calls for the establishment of a Criminal Chamber within this merged African Court to enable it try international crimes. It is a good idea for the continent if we can keep the promises fulfilled. Since there is likelihood to have only one court to address violations of human rights by individuals and states, it would be a good idea. The only problem lies with the funding of this new court.

Furthermore, the process of establishing the Criminal Chamber is contrary to the provisions of the ICC Statute requiring African states, including the AU as an intergovernmental organization, to cooperate fully with the ICC. ${ }^{76}$ This consideration is based on the assumption that the establishment of the Chamber is not motivated by the genuine desire to bring to justice the alleged perpetrators of international crimes, as argued in this paper. It must be recalled that the call for an establishment of the Criminal Chamber has only come when the AU has made it clear that it will not cooperate with the ICC. Besides, the establishment of the proposed Criminal Chamber is also attributable to the fact that many of the African states do not want to cooperate with the ICC in the prosecution of individuals who commit international crimes. This is premised on the fact

\footnotetext{
${ }^{75}$ As of writing, only Burkina Faso, Libya and Mali have ratified the Protocol on the Statute of the African Court of Justice Human Rights. See and <http://www.africancourtcoalition.org/content_files/files/February10.pdf> (visited 19 October 2010).

${ }^{76}$ Art. 87(6) ICCSt.
} 
that many of the African states have signed Bilateral Immunity Agreements with the United States of America not to cooperate with the ICC. ${ }^{77}$

In light of the above, one must therefore question whether the AU has any genuine purpose in establishing such a Criminal Chamber. The only immediate response that one may draw is that the $\mathrm{AU}$ is trying to protect some of its leaders who are very well known for a culture of impunity and commission of serious international crimes against their own citizens. The AU seems to do so albeit in the name of combating impunity in Africa by purporting to establish a Criminal Chamber which will render justice for Africans. Even if such a Criminal Chamber is established, it will never affect the functioning of universal jurisdiction over international crimes, which the national courts in European states have invoked in indicting African leaders.

Even if the Criminal Chamber is established, it remains to be seen whether heads of state will be amenable to prosecution and punishment before such a Chamber. It is not clear whether the AU will be able to do away with the question of immunity attaching to African state officials simply by establishing the Criminal Chamber. It is impracticable for African leaders to sign a treaty establishing a court that would eventually try them no matter whether they have left power or are still in office. Such fears must be clearly expressed given the current trend in Africa where African states have refused to cooperate with the ICC while knowing they had initially signed and ratified the Rome Statute, which unambiguously rejects immunity. ${ }^{78}$

\section{Conclusion}

It is apparent that the AU has simply come up with an idea to establish the proposed Criminal Chamber within the African Court as a way to respond to the indictment of President Omar Hassan Al-Bashir of Sudan as well as Habré of Chad following their indictments by the ICC and Belgian domestic courts, respectively. It is also apparent that the proposed Criminal Chamber will inevitably compete with the ICC in terms of

\footnotetext{
${ }^{77}$ For a detailed study on the African states that have signed Bilateral Agreements with USA, see D. Cotton and G.O. Odongo, 'The Magnificent Seven: Africa's Response to US Article 98' 7African Human Rights Law Journal (2007)1.

${ }^{78}$ Art. 27 ICCSt.
} 
jurisdiction over persons and crimes thereby working against and undermining the ICC in its already well-known competence over international crimes.

Arguments against cooperation with the ICC are flawed in law because some African states are states parties to the Rome Statute and therefore the principle pacta sunt servanda applies. Besides, by refusing to cooperate with the ICC over the prosecution of President Omar Al-Bashir, African states have violated their obligations under customary international law, the Rome Statute and Article 4(o) of the Constitutive Act of the AU. Furthermore, calls for establishment of the Criminal Chamber may be interpreted to defeat the object and purpose of the Rome Statute and to impede the work of the ICC to punish individuals who commit international crimes in Africa.

It is not clear whether, by refusing to cooperate with the ICC over the arrest of President Omar Al Bashir, or that of Colonel Muammar Gaddafi the AU is trying to protect immunity of state officials for international crimes, or to reject impunity as per Article 4(h), (m) and (o) of the Constitutive Act of the AU. The proposed Criminal Chamber is more likely to suffer problems than to render justice for Africa. Hence, there is need for the AU to support the ICC as per the Rome Statute. Particularly, African states parties to the Rome Statute should respect their obligations. The proposed Criminal Chamber does not find its legal basis under the Rome Statute. Nevertheless, a legal basis for the establishment of such courts may be found in Articles I and VI of the Genocide Convention, Article 4(m), (o) of the Constitutive Act of the African Union, and customary international law, in addition to the AU decisions and proposed Protocol on the establishment of the Criminal Chamber within the African Court.

Finally, even if the proposed Criminal Chamber is eventually established, it remains to be seen whether sitting state officials from African states can effectively be prosecuted and punished by this Chamber, and whether African states are prepared to arrest serving or former state officials from other states. It is also important to recall that African states must respect their obligations arising from the principle of universal jurisdiction over international crimes. 